\title{
Evidence for Cretaceous-Paleogene boundary bolide "impact winter" conditions from New Jersey, USA
}

\author{
Johan Vellekoop ${ }^{1 *}$, Selen Esmeray-Senlet ${ }^{2 \S}$, Kenneth G. Miller ${ }^{2}$, James V. Browning ${ }^{2}$, Appy Sluijs ${ }^{1}$, \\ Bas van de Schootbrugge ${ }^{1}$, Jaap S. Sinninghe Damsté ${ }^{3,4}$, and Henk Brinkhuis ${ }^{1,3}$ \\ 'Marine Palynology and Paleoceanography, Department of Earth Sciences, Faculty of Geosciences, and Laboratory of \\ Palaeobotany and Palynology, Utrecht University, Budapestlaan 4, 3584CD Utrecht, Netherlands \\ 2Department of Earth and Planetary Sciences, Rutgers University, 610 Taylor Road, Piscataway, New Jersey 08854, USA \\ ${ }^{3} \mathrm{NIOZ}$ Royal Netherlands Institute for Sea Research, 1790 AB Den Burg, Texel, Netherlands \\ ${ }^{4}$ Geochemistry, Department of Earth Sciences, Faculty of Geosciences, Utrecht University, Budapestlaan 4, 3584CD Utrecht, \\ Netherlands
}

\begin{abstract}
Abrupt and short-lived "impact winter" conditions have commonly been implicated as the main mechanism leading to the mass extinction at the Cretaceous-Paleogene (K-Pg) boundary (ca. $66 \mathrm{Ma}$ ), marking the end of the reign of the non-avian dinosaurs. However, so far only limited evidence has been available for such a climatic perturbation. Here we perform high-resolution $\mathrm{TEX}_{86}$ organic paleothermometry on three shallow cores from the New Jersey paleoshelf, (northeastern USA) to assess the impact-provoked climatic perturbations immediately following the K-Pg impact and to place these short-term events in the context of long-term climate evolution. We provide evidence of impact-provoked, severe climatic cooling immediately following the K-Pg impact. This so-called "impact winter" occurred superimposed on a long-term cooling trend that followed a warm phase in the latest Cretaceous.
\end{abstract}

\section{INTRODUCTION}

The Cretaceous-Paleogene (K-Pg) boundary mass extinction (ca. $66 \mathrm{Ma}$ ) is one of the most devastating events in the history of life, marking the end of the dinosaur era (Bambach, 2006). Although Deccan Traps volcanism may have contributed to environmental perturbations, the mass extinction at the K-Pg boundary is widely acknowledged to be related to the global environmental consequences of the impact of an asteroid with a diameter of $\sim 10 \mathrm{~km}$ at Chicxulub, Mexico (Alvarez et al., 1980). The impact likely caused rapid and profound global climate change (e.g., Kring, 2007) that was superimposed on long-term environmental trends unrelated to the impact. Unraveling climate changes across the $\mathrm{K}-\mathrm{Pg}$ boundary interval is nevertheless complicated because many biotic environmental proxy carriers, such as planktic foraminifera and calcareous nannoplankton, experienced major extinctions and are rare to absent in the earliest Paleocene (e.g., Huber et al., 2002). In contrast, the sea-surface temperature (SST) proxy TEX $_{86}$, based on fossilized membrane lipids of pelagic archaea (Schouten et al., 2002), can be

*Current address: Division of Geology, Department of Earth and Environmental Sciences, KU Leuven, Celestijnenlaan 200E, 3001 Leuven, Belgium; E-mail: johan.vellekoop@kuleuven.be.

${ }^{\S}$ Current address: Chevron Energy Technology Company, 1500 Louisiana St., Houston, Texas 77002, USA. used across the K-Pg boundary (Vellekoop et al., 2014), potentially providing insight into climate changes across this interval.

In a recent study we documented the first indications of rapid short-term cooling following the Chicxulub impact, based on the $\mathrm{TEX}_{86}$-based SST record of Brazos River (Texas, USA; Vellekoop et al., 2014). This record provided the first evidence for cold conditions, from sediments directly overlying the impact and tsunami layers, that are possibly linked to the remnant of the commonly assumed "impact winter" (Alvarez et al., 1980). This dark and cold phase is proposed to have caused a global collapse of terrestrial and marine food webs, ultimately leading to the $\mathrm{K}-\mathrm{Pg}$ boundary mass extinction (Alvarez et al., 1980; Schulte et al., 2010; Vellekoop et al., 2014) Theory suggests that the impact winter was caused by sulfate aerosols, dust, and soot particles ejected into the atmosphere by the impact (Pope et al., 1994). Examples of sulfate aerosol injections into the stratosphere by volcanic eruptions during past millennia confirm that even relatively small injections of sulfate aerosols (100-500 Mt; Legrand and Delmas, 1987; Witter and Self, 2006; Oman et al., 2006) can lead to short-term cooling at regional to global scales, persisting for up to ten years after some of the largest eruptive episodes (Oppenheimer, 2002; Sigl et al., 2015). This argues for a very strong cooling effect resulting from the K-Pg boundary impact, considering the much larger volume of sulfate aerosols generated by the impact (10-200 Gt; Pope et al., 1997; Gupta et al., 2001).

However, so far, unequivocal evidence for the hypothesized impact winter is still lacking, as the cooling signal has only been recorded at Brazos River, where it consists of multiple peaks, spread out over inferred post-impact storm deposits. Moreover, it is unknown how this cooling signal is related to long-term climatic trends unrelated to the impact. Distinguishing shortterm changes directly following the K-Pg boundary impact is complicated by a lack of records of sufficient temporal resolution. Testing the K-Pg boundary impact-winter hypothesis requires the examination of additional stratigraphically complete marine records that are characterized by a good preservation of organic matter and are sufficiently expanded to allow for the detection of relatively fast, transient changes.

The New Jersey paleoshelf K-Pg succession, characterized by clayey glauconitic sands and glauconite clays deposited in a shallow marine setting (Miller et al., 2010; Esmeray-Senlet et al., 2015), may provide suitable sites. In A.D. 2008 and 2009, three new shallow $(<25 \mathrm{~m})$ cores were drilled across the K-Pg boundary in New Jersey (Miller et al., 2010)—Meirs Farm $\left(40^{\circ} 06^{\prime} 15.48^{\prime \prime} \mathrm{N}, 74^{\circ} 31^{\prime} 37.48^{\prime \prime} \mathrm{W}\right)$, Search Farm $\left(40^{\circ} 05^{\prime} 29.20^{\prime \prime} \mathrm{N}, 74^{\circ} 32^{\prime} 16.10^{\prime \prime} \mathrm{W}\right)$, and Fort Monmouth $3\left(40^{\circ} 18^{\prime} 37.18^{\prime \prime} \mathrm{N}, 74^{\circ} 02^{\prime} 46.25^{\prime \prime} \mathrm{W}\right)$ (Fig. 1)—providing records that may be used to unravel both impact-related perturbations as well as the long-term climate changes in the latest Cretaceous-earliest Paleogene interval. Here we provide a biostratigraphic framework for these three cores and present a $\mathrm{TEX}_{86}$ analyses to assess the impact-provoked climatic perturbations immediately following the K-Pg impact and to place these short-term events in a context of a long-term climatic background.

\section{MATERIALS AND METHODS}

The three cores are characterized by Maastrichtian, grayish, bioturbated clayey glauconitic 


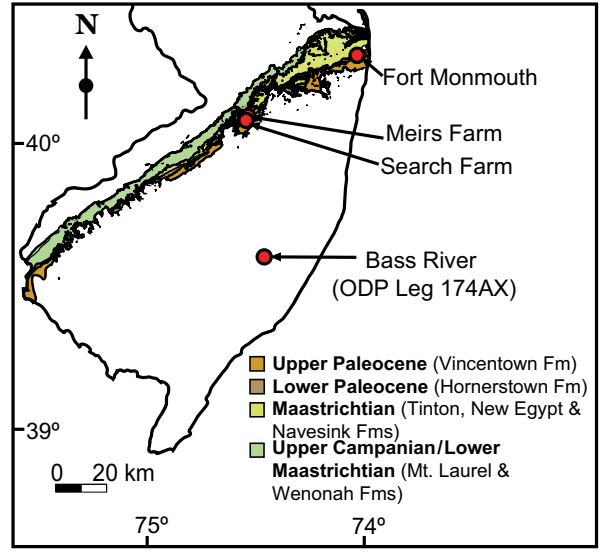

Figure 1. Geological map of part of New Jersey, USA, showing outcropping Maastrichtian and Paleocene formations and locations of Bass River, Meirs Farm, Search Farm, and Fort Monmouth cores. ODP-Ocean Drilling Program.

sands to glauconite clays of the New Egypt Formation, overlain by heavily bioturbated clayey glauconitic sands of the Danian Hornerstown Formation, deposited at an inner neritic setting (water depth of <35 m; Miller et al., 2010; Esmeray-Senlet et al., 2015).

Organic-walled dinoflagellate cysts (dinocysts), abundantly present in these deposits (Habib and Saeedi, 2007), serve as reliable chronobiostratigraphic tools (Williams et al., 2004), especially at shallow marine sites (Brinkhuis and Schiøler, 1996; Vellekoop et al., 2014). By combining high-resolution dinocyst and planktic foraminiferal biostratigraphy with the analyses of iridium using high-sensitivity sector fieldinductively coupled plasma-mass spectrometry, we generated a detailed age model for the three investigated cores (Fig. 2; see the GSA Data Repository $^{1}$ ).

We extracted glycerol dialkyl glycerol tetraethers (GDGTs) from 55 samples using organic solvents, and quantified the various GDGTs using high-performance liquid chromatography-mass spectrometry. We used $\mathrm{TEX}_{86}^{\mathrm{H}}$ (based on the isoprenoid GDGT distribution) to estimate absolute SSTs using the Kim et al. (2010) modern core-top calibration, which has a calibration error of $2.5^{\circ} \mathrm{C}$. Although several factors can potentially cause $\mathrm{TEX}_{86}$-inferred SSTs to deviate from actual SSTs, e.g., low oxygen concentrations and the input of soil organic matter or methanogenic and methanotrophic archaeal GDGTs (e.g., Schouten et al., 2013), these factors likely do not play a major role at the Cretaceous-Paleogene New Jersey shelf. For a more detailed discussion on factors potentially influencing TEX ${ }_{86}$ results, see the Data Repository.

${ }^{1}$ GSA Data Repository item 2016201, materials and methods, is available online at www.geosociety .org/pubs/ft2016.htm, or on request from editing@ geosociety.org.

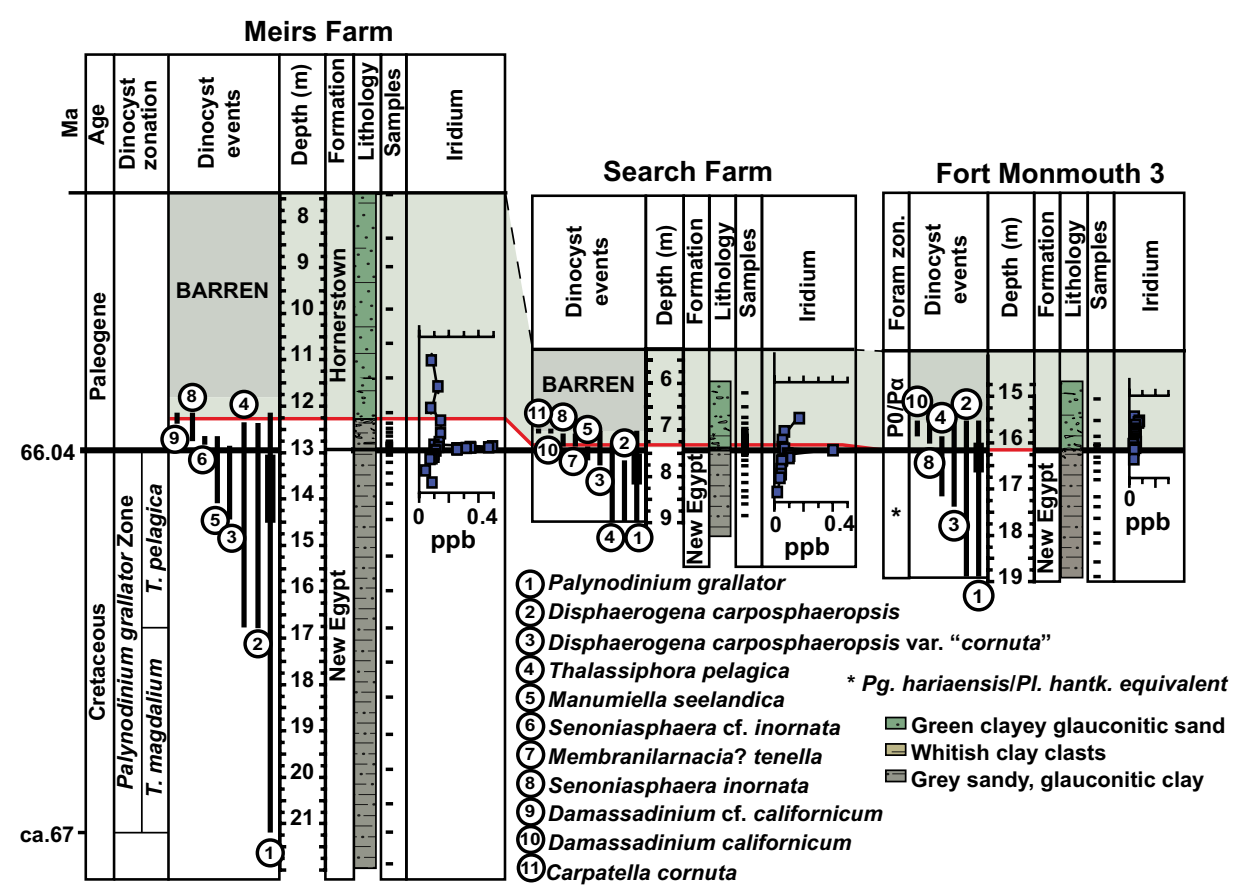

Figure 2. Stratigraphic correlation between Meirs Farm, Search Farm, and Fort Monmouth 3 cores (New Jersey, USA), with ranges of dinocyst marker taxa. Dinocyst zonation is based on Hansen (1977). Iridium records of Meirs Farm and Search Farm are from Miller et al. (2010); that of Fort Monmouth 3 is from this study. T. magdalium-Tanyosphaeridium magdalium; T. pelagica-Thalassiphora pelagica; Pg. hariaensis-Pseudoguembelina hariaensis; PI. hantk.-Plummerita hantkeninoides; zon.-zonation.

\section{RESULTS AND DISCUSSION}

Our age model (Fig. 2; Figs. DR1-DR3 in the Data Repository) shows that our combined record ranges from $\sim 1.1$ m.y. before the $\mathrm{K}-\mathrm{Pg}$ boundary to $>100 \mathrm{k} . \mathrm{y}$. after the boundary, based on the biochronology of Gradstein et al. (2012) where the K-Pg boundary is placed at $66.04 \mathrm{Ma}$ The high-resolution dinocyst biostratigraphy, in particular the presence of the lowermost Danian marker Senoniasphaera cf. inornata, shows that the earliest Paleocene interval, equivalent to the lowermost Paleogene planktic foraminiferal zone P0 (Vellekoop et al., 2014; Açikalin et al., 2015), is represented in the Meirs Farm core (Fig. 2; see the Data Repository). Therefore, this core can be used to reconstruct transient climate changes in the immediate post-impact interval.

The TEX ${ }_{86}$ records show changes in SST that are consistent among cores (Fig. 3). The lowermost interval, approximately representing the interval ca. 67.1-66.8 Ma, is characterized by a gradual cooling from $25.5-26.0^{\circ} \mathrm{C}$ to $\sim 24-25$ ${ }^{\circ}$ C. Subsequently, there was a steady warming of $\sim 2{ }^{\circ} \mathrm{C}$ until approximately $\sim 300-400 \mathrm{k}$.y. before the K-Pg boundary, followed by a stronger warming of $\sim 3{ }^{\circ} \mathrm{C}$, reaching SSTs of up to $29.0^{\circ} \mathrm{C}$. These results are consistent amongst the cores and are comparable to the previously reported $\delta^{18} \mathrm{O}$ temperature records from the nearby Ancora and Bass River cores (Ocean Drilling Program [ODP] Leg 174AX) (Olsson et al., 2002; Esmeray-Senlet et al., 2015) (Fig. 3). Based on correlation with a globally recorded shift in osmium isotope records near the base of subchron C29R (Robinson et al., 2009), it has been suggested that the warming phase in the latest Maastrichtian is related to a significant outpouring phase of the Deccan Traps large igneous province (Courtillot et al., 1986; Olsson et al., 2002). Our TEX ${ }_{86}$ SST record indicates that this warming phase ended several tens of thousands of years before the K-Pg boundary impact with the onset of a gradual cooling trend that spans the K-Pg boundary. This is in agreement with earlier published paleotemperature records (e.g., Olsson et al., 2002).

Immediately above the K-Pg boundary, within the initial post-impact phase, the $\mathrm{TEX}_{86}$ record displays a short-lived distinct cooling event of $\sim 3{ }^{\circ} \mathrm{C}$ superimposed on the general cooling trend. The cooling is recognized in two to three earliest Paleocene samples in the Meirs Farm core and in one sample from the boundary clay cast layer at Search Farm (Fig. 3). Although only recorded in a few samples, it is consistent between cores and is therefore considered a robust signal. Our high-resolution dinocyst biostratigraphy shows that this cooling event occurred within the interval equivalent to the basal part of the lowermost Paleogene planktic foraminiferal zone P0 (Fig. 4; see the Data Repository). This interval, $<5 \mathrm{~cm}$ thick (Fig. 4), represents the earliest Paleocene, corresponding to the first millennia following the K-Pg boundary impact (see the Data Repository). However, given that there is evident bioturbation within this interval, it is expected that 

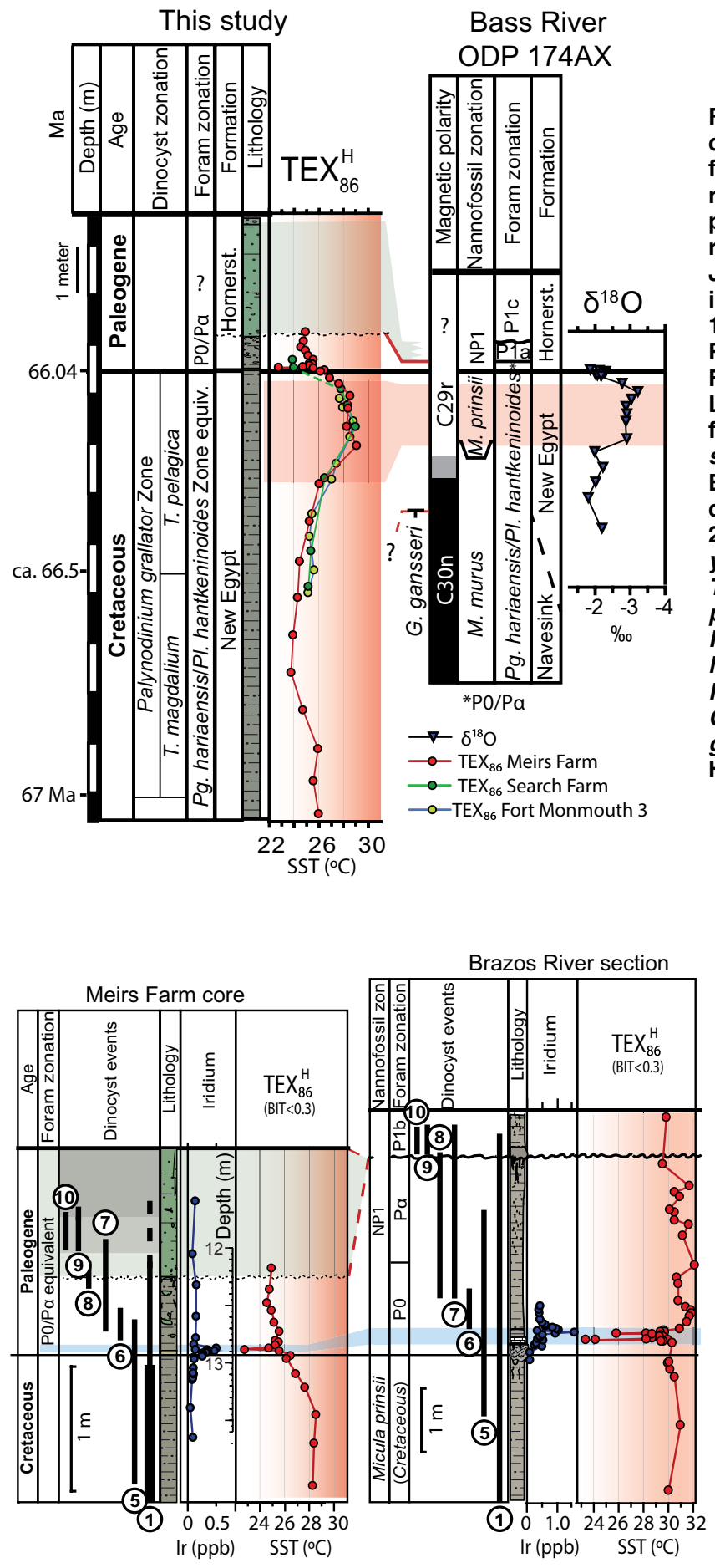

Figure 3. Splice of studied cores with TEX $_{86}$ sea-surface temperature (SST) records, correlated to planktic foraminiferal $\delta^{18} 0$ record of Bass River (New Jersey, USA), Ocean Drilling Program (ODP) Leg 174AX (Olsson et al., 2002). Records are to scale. (See Fig. 2 for lithology symbols.) Last occurrence of planktic foraminiferal marker Gansserina gansseri is based on Esmeray-Senlet et al. (2015), ca. $66.49 \mathrm{Ma}$ (Gradstein et al., 2012). T. magdalium-Tanyosphaeridium magdalium T. pelagica-Thalassiphora pelagica; Pg. hariaensisPseudoguembelina hariaensis; PI. hantk.Plummerita hantkeninoides; G. gansseri-Gansserina gansseri; M.-Micula Hornerst.-Hornerstown.

Figure 4. Meirs Farm (New Jersey, USA) TEX sea-surface temperature (SST) record correlated to TEX TST $_{86}$ SST record of Brazos River (Texas, USA) (Vellekoop et al. 2014). For dinocyst species numbers and lithology symbols, see Figure 2. Iridium record of Meirs Farm is from Miller et al. (2010); that of Brazos River is from Rocchia et al. (1996). zon-zonation; BIT-Brached Isoprenoid Tetraether index. Meirs Farm and Brazos River records are on a scale of 1:2.

considerable smoothing of the cooling signal has occurred. Therefore, the cooling spike within the TEX $_{86}$ SST record possibly represents an even shorter event. Similar to the event indicated in the Brazos River TEX ${ }_{86}$ record (Vellekoop et al., 2014), the cooling event at the New Jersey paleoshelf precisely coincides with the iridium anomaly (Fig. 4) which reflects dust derived from the asteroid (Schulte et al., 2010). This suggests that the cool phase may have occurred on a similar time scale as the settling of impact dust. Modern-day examples of dust injections impact dust. With high-energy events such as nuclear explosions and asteroid impacts, small dust particles are likely to be knocked higher into the stratosphere than for example by volcanic eruptions (Robock et al., 2007). Hence, whereas dust produced by volcanoes and burning oil wells has residence times of months to years (MacKinnon et al., 1984; Hobbs and Radke, 1992; Oman et al., 2006), dust particles produced by large impacts likely have residence times of multiple years (Robock et al., 2007). Therefore, the iridium spike at the New Jersey paleoshelf likely represents a time interval of several decades at most. The cooling signal recorded by the $\mathrm{TEX}_{86}$ record therefore possibly reflects a very shortlived cooling event, with a duration of several decades to centuries. Accordingly, our TEX 86 record provides evidence for a short-lived impact winter, possibly within the first centuries following the K-Pg boundary bolide impact.

In contrast to the record of Brazos River, which shows relatively high temperatures following the impact winter relative to the latest Cretaceous (Vellekoop et al., 2014), the TEX ${ }_{86}$ record from the Meirs Farm and Search Farm cores indicates that slightly cooler conditions persisted after the impact winter, consistent with the Tunisian shelf records (Galeotti et al., 2004; Vellekoop et al., 2015). The preservation of organic matter is poorer in the bioturbated, green, glauconitic sand of the Hornerstown Formation, resulting in less reliable $\mathrm{TEX}_{86}$ results for this interval.

\section{SUMMARY AND IMPLICATIONS}

Our new $\mathrm{TEX}_{86}$ record portrays latest Cretaceous warming, possibly related to volcanic outpouring by the Deccan Traps. Gradual cooling occurred during the last tens of thousands of years of the Cretaceous, with a short, transient cooling event immediately following the K-Pg boundary impact. Together, the TEX ${ }_{86}$ records from the New Jersey shelf and Brazos River, Texas, provide firm evidence for a shortlived, very severe cooling directly following the K-Pg boundary, likely reflecting a global "impact winter" caused by the Chicxulub impact. This global, rapid, short-term cooling is likely caused by the darkness in the first decades after the impact, resulting from the injection of dust, soot, and sulfur aerosols into the atmosphere, partially blocking incoming solar radiation (Pope et al., 1994). The dark phase following the impact temporarily inhibited photosynthesis, causing a global collapse of terrestrial and marine food webs, leading to the mass extinction at the K-Pg boundary (Alvarez et al., 1980). Thus, our TEX ${ }_{86}$ SST record shows long-term latest Maastrichtian environmental changes, as well as the K-Pg boundary bolide impact winter, presenting the first record to display both longterm climatic trends across the K-Pg boundary interval and short-term changes related to the K-Pg boundary impact within the same record.

\section{ACKNOWLEDGMENTS}

We thank N. Welters and J. Ossebaar for analytical assistance. Funding for this research was provided by the Netherlands Organization for Scientific Research (grant ALWPJ/09047 to Brinkhuis and Sinninghe Damsté), the U.S. National Science Foundation 63759 to Miller), the European Research Council (Starting Grant 259627 to Sluijs), and the German (grants EAR 070778, OCE-0751757, and OCE14- 
Science Foundation (DFG grant SCHOO1216-6 to van de Schootbrugge). This work was partially carried out under the program of the Netherlands Earth System Science Centre (NESSC), financially supported by the Dutch Ministry of Education, Culture and Science (OCW). We would like to thank the three anonymous reviewers for their comments and suggestions.

\section{REFERENCES CITED}

Açikalin, S., et al., 2015, Geochemical and palaeontological characterization of a new K-Pg boundary locality from the northern branch of the NeoTethys: Mudurnu-Göynük Basin, NW Turkey: Cretaceous Research, v. 52, p. 251-267, doi:10 .1016/j.cretres.2014.07.011

Alvarez, L.W., Alvarez, W., Asaro, F., and Michel, H.V., 1980, Extraterrestrial cause for the CretaceousTertiary extinction: Science, v. 208, p. 1095-1108, doi:10.1126/science.208.4448.1095.

Bambach, R.K., 2006, Phanerozoic biodiversity mass extinctions: Annual Review of Earth and Planetary Sciences, v. 34, p. 127-155, doi:10.1146 /annurev.earth.33.092203.122654.

Brinkhuis, H., and Schiøler, P., 1996, Palynology of the Geulhemmerberg Cretaceous/Tertiary boundary section (Limburg, SE Netherlands): Geologie \& Mijnbouw, v. 75, p. 193-213.

Courtillot, V., Besse, J., Vandamme, D., Montigny, R., Jaeger, J.-J., and Capetta, H., 1986, Deccan flood basalts at the Cretaceous/Tertiary boundary?: Earth and Planetary Science Letters, v. 80, p. 361-374, doi:10.1016/0012-821X(86)90118-4.

Esmeray-Senlet, S., Wright, J.D., Olsson, R.K., Miller, K.G., Browning, J.V., and Quan, T.M., 2015, Evidence for reduced export productivity following the Cretaceous/Paleogene mass extinction: $\mathrm{Pa}$ leoceanography, v. 30, p. 718-738, doi:10.1002 /2014PA002724.

Galeotti, S., Brinkhuis, H., and Huber, M., 2004 Records of post-Cretaceous-Tertiary boundary millennial-scale cooling from the western Tethys: A smoking gun for the impact-winter hypothesis?: Geology, v. 32, p. 529-532, doi: 10.1130/G20439.1.

Gradstein, F.M., Ogg, J.G., Schmitz, M.D., and Ogg, G.M., 2012, The Geologic Time Scale 2012, Volumes 1 and 2: Boston, Elsevier, 1144 p., doi: 10 .1016/B978-0-444-59425-9.00004-4.

Gupta, S.C., Ahrens, T.J., and Yang, W., 2001, Shockinduced vaporization of anhydrite and global cooling from the K/T impact: Earth and Planetary Science Letters, v. 188, p. 399-412, doi:10.1016 /S0012-821X(01)00327-2.

Habib, D., and Saeedi, F., 2007, The Manumiella see landica global spike: Cooling during regression at the close of the Maastrichtian: Palaeogeography, Palaeoclimatology, Palaeoecology, v. 255, p. 87-97, doi:10.1016/j.palaeo.2007.02.043.

Hansen, J.M., 1977, Dinoflagellate stratigraphy and echinoid distribution in Upper Maastrichtian and Danian deposits from Denmark: Bulletin of the Geological Society of Denmark, v. 26, p. 1-26.

Hobbs, P.V., and Radke, L.F., 1992, Airborne studies of the smoke from the Kuwait oil fires: Science, v. 256, p. 987-991, doi:10.1126/science 256.5059.987.

Huber, B.T., MacLeod, K.G., and Norris, R.D., 2002, Abrupt extinction and subsequent reworking of Cretaceous foraminifera across the CretaceousTertiary boundary: Evidence from the subtropical North Atlantic, in Koeberl, C., and MacLeod,
K.G., eds., Catastrophic Events and Mass Extinctions: Impacts and Beyond: Geological Society of America Special Paper 356, p. 277-289, doi: 10.1130/0-8137-2356-6.277

Kim, J.H., van der Meer, J., Schouten, S., Helmke, P., Willmott, V., Sangiorgi, F., Koç, N., Hopmans, E.C., and Sinninghe Damsté, J.S., 2010, New indices and calibrations derived from the distribution of crenarchaeal isoprenoid tetraether lipids: Implications for past sea surface temperature reconstructions: Geochimica et Cosmochimica Acta, v. 74, p. 4639-4654, doi:10.1016/j.gca 2010.05.027

Kring, D.A., 2007, The Chicxulub impact event and its environmental consequences at the CretaceousTertiary boundary: Palaeogeography, Palaeoclimatology, Palaeoecology, v. 255, p. 4-21, doi: 10 .1016/j.palaeo.2007.02.037.

Legrand, M., and Delmas, R., 1987, A 220 year continuous record of volcanic $\mathrm{H}_{2} \mathrm{SO}_{4}$ in the Antarctic ice sheet: Nature, v. 327, p. 671-676, doi:10 .1038/327671a0.

MacKinnon, I.D.R., Gooding, J.L., McKay, D.S., and Clanton, U.S., 1984, The E1 Chichón stratospheric cloud: Solid particulates and settling rates: Journal of Volcanology and Geothermal Research, v. 23, p. 125-146, doi:10.1016/0377 -0273(84)90059-3.

Miller, K.G., Sherrell, R.M., Browning, J.V., Field, M.P., Gallagher, W., Olsson, R.K., Sugarman, P.J., Tuorto, S., and Wahyudi, H., 2010, Relationship between mass extinction and iridium across the Cretaceous-Paleogene boundary in New Jersey: Geology, v. 38 , p. $867-870$, doi: 10.1130 /G31135.1.

Olsson, R.K., Miller, K.G., Browning, J.V., Wright, J.D., and Cramer, B.S., 2002, Sequence stratigraphy and sea-level change across the CretaceousTertiary boundary on the New Jersey passive margin, in Koeberl, C., and MacLeod, K.G., eds., Catastrophic Events and Mass Extinctions: Impacts and Beyond: Geological Society of America Special Paper 356, p. 97-108, doi:10.1130/0 -8137-2356-6.97.

Oman, L., Robock, A., Stenchikov, G.L., Thordarson, T., Koch, D., Shindell, D.T., and Gao, C., 2006, Modeling the distribution of the volcanic aerosol cloud from the 1783-1784 Laki eruption: Journal of Geophysical Research, v. 111, D12209, doi: 10.1029/2005JD006899.

Oppenheimer, C., 2002, Limited global change due to the largest known Quaternary eruption, Toba $\approx 74$ kyr BP?: Quaternary Science Reviews, v. 21, p. 1593-1609, doi:10.1016/S0277-3791 (01)00154-8

Pope, K.O., Baines, K.H., Ocampo, A.C., Ivanov, B.A., 1994, Impact winter and the Cretaceous/ Tertiary extinctions: Results of a Chicxulub asteroid impact model: Earth and Planetary Science Letters, v. 128, p. 719-725, doi:10.1016/0012 -821X(94)90186-4

Pope, K.O., Baines, K.H., Ocampo, A.C., and Ivanov, B.A., 1997, Energy, volatile production, and climatic effects of the Chicxulub Cretaceous-Tertiary impact: Journal of Geophysical Research, v. 102, p. 21,645-21,664, doi:10.1029 197JE01743.

Robinson, N., Ravizza, G., Coccioni, R., PeuckerEhrenbrink, B., and Norris, R., 2009, A highresolution marine ${ }^{187} \mathrm{Os} /{ }^{188} \mathrm{Os}$ record for the late Maastrichtian: Distinguishing the chemical fingerprints of Deccan volcanism and the KP impact event: Earth and Planetary Science Letters, v. 281, p. 159-168, doi:10.1016/j.eps1.2009.02.019.

Robock, A., Oman, L., and Stenchikov, G.L., 2007, Nuclear winter revisited with a modern climate model and current nuclear arsenals: Still catastrophic consequences: Journal of Geophysical Research, v. 112, D13107, doi:10.1029 12006JD008235.

Rocchia, R., Robin, E., Froget, L., and Gayraud, J., 1996, Stratigraphic distribution of extraterrestrial markers at the Cretaceous-Tertiary boundary in the Gulf of Mexico area: Implications for the temporal complexity of the event, in Ryder, G., et al., eds., The Cretaceous-Tertiary Event and Other Catastrophes in Earth History: Geological Society of America Special Paper 307, p. 279-286, doi:10.1130/0-8137-2307-8.279.

Schouten, S., Hopmans, E.C., Schefuß, E., and Sinninghe Damsté, J.S., 2002, Distributional variations in marine crenarchaeotal membrane lipids: A new tool for reconstructing ancient sea water temperatures?: Earth and Planetary Science Letters, v. 204, p. 265-274, doi:10.1016/S0012 821X(02)00979-2.

Schouten, S., Hopmans, E.C., and Sinninghe Damsté, J.S., 2013, The organic geochemistry of glycerol dialkyl glycerol tetraether lipids: A review: Organic Geochemistry, v. 54, p. 19-61, doi:10.1016 /j.orggeochem.2012.09.006.

Schulte, P., et al., 2010, The Chicxulub asteroid impact and mass extinction at the Cretaceous-Paleogene boundary: Science, v. 327, p. 1214-1218, doi:10 $.1126 /$ science. 1177265 .

Sigl, M., et al., 2015, Timing and climate forcing of volcanic eruptions for the past 2,500 years: Nature, v. 523, p. 543-549, doi:10.1038 /nature 14565.

Vellekoop, J., Sluijs, A., Smit, J., Schouten, S., Weijers, J.W.H., Sinninghe Damsté, J.S., and Brinkhuis, H., 2014, Rapid short-term cooling following the Chicxulub impact at the Cretaceous-Paleogene boundary: Proceedings of the National Academy of Sciences of the United States of America, v. 111, p. 7537-7541, doi:10.1073/pnas 1319253111.

Vellekoop, J., Smit, J., van de Schootbrugge, B., Weijers, J.W.H., Galeotti, S., Sinninghe Damsté, J.S., and Brinkhuis, H., 2015, Palynological evidence for prolonged cooling along the Tunisian continental shelf following the K-Pg boundary impact: Palaeogeography, Palaeoclimatology, $\mathrm{Pa}-$ laeoecology, v. 426, p. 216-228, doi:10.1016/j palaeo.2015.03.021

Williams, G.L., Brinkhuis, H., Pearce, M.A., Fensome, R.A., and Weegink, J.W., 2004, Southern Ocean and global dinoflagellate cyst events compared: Index events for the Late Cretaceous-Neogene, in Exon, N.F., et al., eds., Proceedings of the Ocean Drilling Program, Scientific Results, Volume 189: College Station, Texas, Ocean Drilling Program, 98 p., doi:10.2973/odp.proc.sr.189 107.2004

Witter, J.B., and Self, S., 2006, The Kuwae (Vanuatu) eruption of AD 1452: Potential magnitude and volatile release: Bulletin of Volcanology, v. 68 , p. 1-18, doi:10.1007/s00445-006-0075-4.

Manuscript received 4 April 2016

Revised manuscript received 2 June 2016

Manuscript accepted 7 June 2016

Printed in USA 